\title{
Texture Development in Alumina Composites by Slip Casting in a Strong Magnetic Field
}

\author{
Tohru S. SUZUKI, Tetsuo UCHIKOSHI and Yoshio SAKKA \\ National Institute for Materials Science, 1-2-1, Sengen, Tsukuba-shi, Ibaraki 305-0047
}

\author{
強磁場中スリップキャストにより作製したアルミナコンポジットにおける配向の発達 \\ 鈴木＼cjkstart達·打越哲郎·目 義雄 \\ (独)物質・材料研究機構 材料研究所, 305-0047 茨城県つくば市千現 1-2-1
}

\begin{abstract}
Magnetic susceptibility is very small in feeble magnetic ceramics such as alumina, consequently, it had been very difficult to develop a textured microstructure in these ceramics by using a magnetic field. We have demonstrated, however, that textured microstructures in alumina, titania, zinc oxide can be prepared by colloidal processing in a high magnetic field followed by sintering. We applied this processing technique to alumina based composites. The degree of crystallographic texture was small in specimen sintered at the low temperature. The degree of orientation increased rapidly with increasing sintering temperature and depended on the grain size of alumina matrix. The grain size can be controlled by the content of YTZ particle as a second phase, the kind of dopant, sintering temperature, annealing temperature and annealing time.
\end{abstract}

[Received September 22, 2005; Accepted November 17, 2005]

Key-words : Crystalline texture, Strong magnetic field, Grain growth, Alumina composite, $\mathrm{ZrO}_{2}, \mathrm{TiO}_{2}, \mathrm{MgO}$

1. Introduction

The controlled development of texture has recently become a topic of interest in materials processing, because it allows improved tailoring of the properties of a material. Many studies have been reported for production of textured ceramics such as by hot forging, ${ }^{1)}$ the Templated Grain Growth method, ${ }^{2,3)}$ the RBAO (reaction bonding of aluminum oxide) technique $^{4)}$ and an extrusion process. ${ }^{5)}$ A magnetic field has been used for controlling the texture in ferromagnetic materials. A crystal possessing magnetic susceptibility anisotropy, when placed in a magnetic field, will rotate by the magnetic torque generated from the interaction between the anisotropic susceptibility and a magnetic field. The reduction of the magnetic energy on rotation is the driving force for magnetic alignment.

On the other hand, it has been generally difficult to apply a magnetic field to diamagnetic ceramics such as $\mathrm{Al}_{2} \mathrm{O}_{3}$, $\mathrm{TiO}_{2}$ and $\mathrm{ZnO}$, because their susceptibility is extremely small. Recently, the development of superconducting magnet technologies has enhanced the application of strong magnetic fields to various academic fields. Some interesting phenomena in strong magnetic fields have been reported, ${ }^{6), 7)}$ and magnetic fields have been used to produce a textured microstructure.$^{8)-10)}$ We also demonstrate that a texture in diamagnetic ceramics can be controlled by colloidal processing with a high magnetic field. ${ }^{11)-14)}$ Colloidal processing is very effective for consolidating fine particles by using repulsive surface forces to avoid heterogeneous agglomerates. ${ }^{15)}$ In order to control the texture using a magnetic field, a good dispersion of powder in a suspension is necessary because a strong attractive force between the agglomerated particles prevents each particle in a suspension from rotating in the magnetic field. Thus, a strong magnetic field was applied to dispersed particles in stable suspensions during slip casting, to cause the particles to rotated during consolidation.

In previous reports, we have pointed out that the degree of crystalline orientation increased during sintering, and we have suggested that the crystalline orientation seems to be inseparably related to the microstructure. ${ }^{11)-14)}$ This report studies the process of texture development in $\mathrm{Al}_{2} \mathrm{O}_{3}$ composites formed in a magnetic field and tries to clarify its relation to their microstructures with the controlled grain size.

In order to control the grain size of $\mathrm{Al}_{2} \mathrm{O}_{3}$, it is possible that $\mathrm{TiO}_{2}$ and $\mathrm{MgO}$ are doped and $\mathrm{YTZ}$ particles are dispersed as a second phase. During sintering of $\mathrm{Al}_{2} \mathrm{O}_{3}$, the addition of $\mathrm{TiO}_{2}$ in small amount is known to enhance densification and promote grain growth. ${ }^{16)-18)}$ By contrast, it is recognized that the addition of $\mathrm{MgO}$ in small amount effectively suppress the abnormal grain growth of $\mathrm{Al}_{2} \mathrm{O}_{3}{ }^{19)}$ and $\mathrm{YTZ}$ particles also prevent the $\mathrm{Al}_{2} \mathrm{O}_{3}$ grain growth by the pining effect. ${ }^{20), 21 \text { ) }}$

\section{Experimental procedure}

A commercially available $\alpha-\mathrm{Al}_{2} \mathrm{O}_{3}$ powder with average particle sizes of $0.15 \mu \mathrm{m}$, spherical and high purity was used as a starting material. $3 \mathrm{~mol} \% \quad \mathrm{Y}_{2} \mathrm{O}_{3}$ stabilized tetragonal $\mathrm{ZrO}_{2}$ (YTZ) spherical powder with an average particle size of $60 \mathrm{~nm}$ was used as the dispersed particle. $\mathrm{TiO}_{2}$ and $\mathrm{MgO}$ spherical powders with average particle sizes of $30 \mathrm{~nm}$ and $0.1 \mu \mathrm{m}$, respectively, were used as additives. Aqueous suspensions containing $30 \mathrm{vol} \%$ solids of pure $\mathrm{Al}_{2} \mathrm{O}_{3}, \mathrm{Al}_{2} \mathrm{O}_{3}$ to which various amounts of $\mathrm{YTZ}$ was added, $\mathrm{Al}_{2} \mathrm{O}_{3}$ with 0.25 mass $\% \mathrm{TiO}_{2}$ addition, and $\mathrm{Al}_{2} \mathrm{O}_{3}$ with 0.03 mass $\% \mathrm{MgO}$ addition were prepared. Polyelectrolyte (poly (ammonium acrylate)) was suitably added at a ratio of $8.76 \times 10^{-6} \mathrm{~kg}$ per weight of $\mathrm{Al}_{2} \mathrm{O}_{3}$ powders and $9.29 \times 10^{-6} \mathrm{~kg}$ per weight of $\mathrm{ZrO}_{2}$ powders into the suspension ${ }^{22}$ as a dispersant. The dispersant for $\mathrm{TiO}_{2}$ and $\mathrm{MgO}$ is so little as to be neglected, because the amounts of them were too small. When suspensions consist of particles with different size and density, segregation occurs because of differences in the sedimentation rate during slip casting. ${ }^{23), 24)}$ Segregation has been shown to be inhibited by hindering sedimentation if the solid content exceeds $30 \mathrm{vol} \%$ in suspension. ${ }^{25)}$ The suspensions were ultrasonicated for $10 \mathrm{~min}$ and stirred for more than $8 \mathrm{~h}$ to disperse the powder. ${ }^{26)}{ }^{27)}$ Elec- 
trosteric stabilization was used to disperse the fine particles and was achieved by polyelectrolyte adsorption on the surface of the particles. ${ }^{28)}{ }^{29)}$ The amounts of polyelectrolyte for maximum dispersion for each powder were determined from viscosity experiments done previously. The suspensions were then consolidated by slip casting after a vacuum desiccator was used to remove as many air bubbles as possible. A strong magnetic field of $10 \mathrm{~T}$ was applied to the suspension during slip casting at room temperature. The direction of the magnetic field was parallel to the casting direction. After slip casting in the magnetic field, the green compacts were further densified by cold isostatic pressing (CIP) at $392 \mathrm{MPa}$ without disturbing the particle orientations. The green bodies were fired isothermally at the desired sintering temperature in air without a magnetic field.

Density measurements were made in kerosene by Archimedes method. The samples were polished and then thermally etched for microstructural analysis using a scanning electron microscope (SEM). Grain size measurements were made on the surface parallel to the magnetic field using the linear intercept method. And the average $\mathrm{Al}_{2} \mathrm{O}_{3}$ grain size perpendicular to a magnetic field was measured, because the anisotropic grain shape during grain growth was taken into consideration. The degree of crystalline texture was determined using the intensities of X-ray diffraction measurements and Eq. (1) below.

$$
P=\frac{I_{006}}{I_{006}+I_{110}}
$$

where $I_{006}$ and $I_{110}$ are the intensities from the 006 and the 110 reflections of $\mathrm{Al}_{2} \mathrm{O}_{3}$ phase on the surface perpendicular to the magnetic field, respectively. The degree of crystalline texture increases as the value of $P$ approaches unity. The number of the grains with the basal plane completely perpendicular to the magnetic field is regarded as the orientation when we use Eq. (1).

\section{Results and discussions}

Figure 1 illustrates the XRD profiles of a specimen which was compacted by slip casting in a strong magnetic field of $10 \mathrm{~T}$ and sintered at $1873 \mathrm{~K}$ for $2 \mathrm{~h}$. The profile of the random $\mathrm{Al}_{2} \mathrm{O}_{3}$ prepared without applying a magnetic field is shown in the bottom of Fig. 1. For comparison, in the surface perpendicular to the magnetic field ( $T$-plane) of other textured $\mathrm{Al}_{2} \mathrm{O}_{3}$, the intensities of the $00 \mathrm{l}$ reflection peaks were very large and the intensity of the (1010) peak at an angle of $17.5^{\circ}$ with the basal plane was also large. It was clear that even in $\mathrm{Al}_{2} \mathrm{O}_{3}$ with various additives addition the development of crystalline orientation could be controlled by the strong magnetic field and the basal plane of $\mathrm{Al}_{2} \mathrm{O}_{3}$ were perpendicular to the applied magnetic field. That is, the $c$ axis was parallel to the magnetic field.

For the YTZ-dispersed $\mathrm{Al}_{2} \mathrm{O}_{3}$ shown in Fig. 2, in the surface perpendicular to the magnetic field ( $T$-plane), the $(006)$ and (0012) peaks appeared and the intensity of the (1010) peak was large. According to the International Center for Diffraction Data (ICDD), the relative intensity of 006 reflection is only hundredth part of that of 113 reflection which is main peak in $\mathrm{Al}_{2} \mathrm{O}_{3}$, thus this (006) peak is hardly observed in general. In contrast with the $T$-plane, in the surface parallel to the magnetic field ( $S$-plane), the intensities of (110) and (300) peaks were large. Accordingly, orientation of the $\mathrm{Al}_{2} \mathrm{O}_{3}$ matrix with the $c$ axis parallel to the magnetic field was also confirmed, but the degree of crystallographic orientation was smaller than that of other $\mathrm{Al}_{2} \mathrm{O}_{3}$ in Fig. 1 and the random

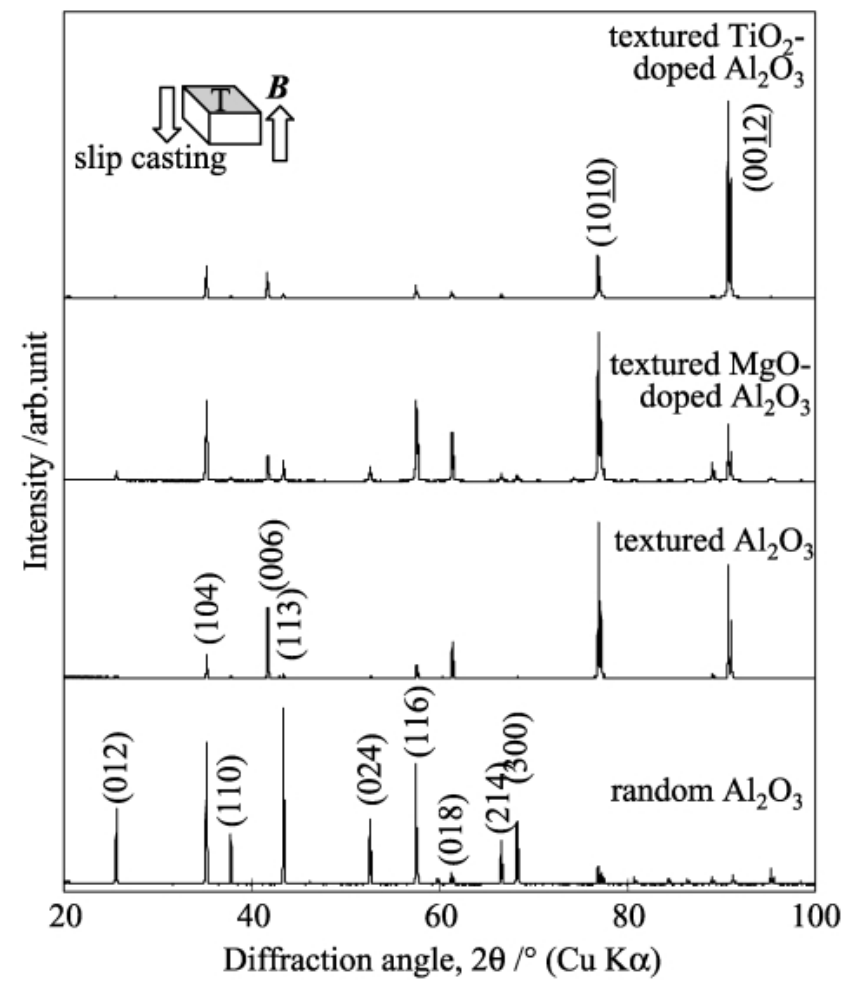

Fig. 1. X-ray diffraction profiles of $\mathrm{Al}_{2} \mathrm{O}_{3}$ prepared by slip casting in a magnetic field $(10 \mathrm{~T})$, followed by sintering at $1873 \mathrm{~K}$ for $2 \mathrm{~h}$, in the plane perpendicular to a magnetic field, which is parallel to the casting direction. By comparison, the bottom of profile is the random $\mathrm{Al}_{2} \mathrm{O}_{3}$ prepared by slip casting without a magnetic field and sintered at $1873 \mathrm{~K}$ for $2 \mathrm{~h}$.

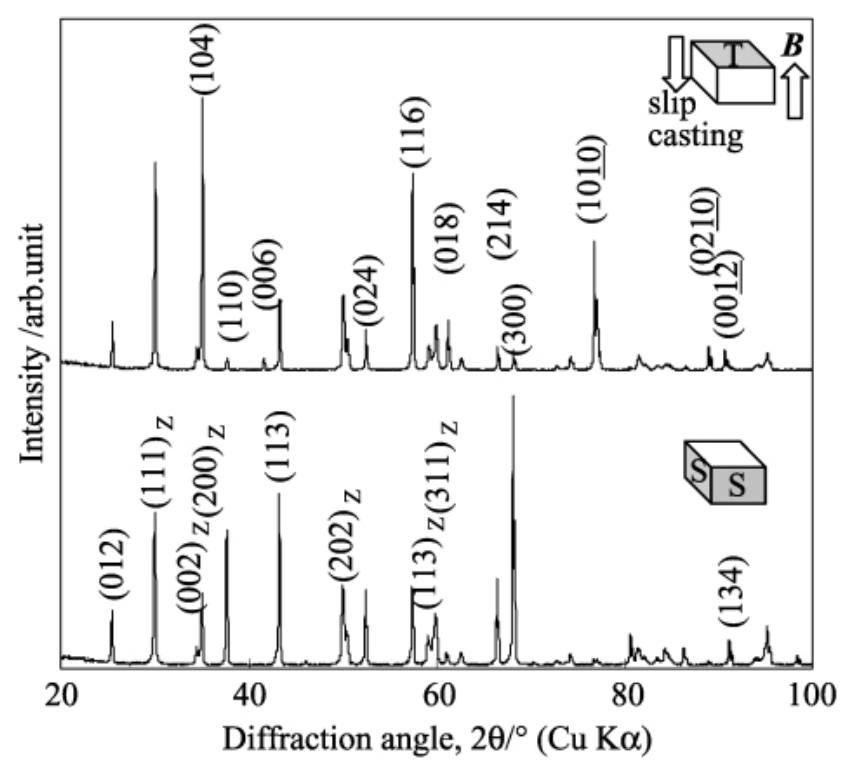

Fig. 2. X-ray diffraction profiles of 15 mass $\%$ YTZ-dispersed $\mathrm{Al}_{2} \mathrm{O}_{3}$ prepared by slip casting in a magnetic field $(10 \mathrm{~T})$, followed by sintering at $1873 \mathrm{~K}$ for $2 \mathrm{~h}$, in the plane perpendicular and parallel to a magnetic field, which is parallel to the casting direction. The subscript of " $z$ " indicates the peaks of YTZ.

orientation of $\mathrm{ZrO}_{2}$ with tetragonal phase was observed.

Figure 3 shows the degree of crystalline texture calculated using Eq. (1) together with the densities as a function of the 


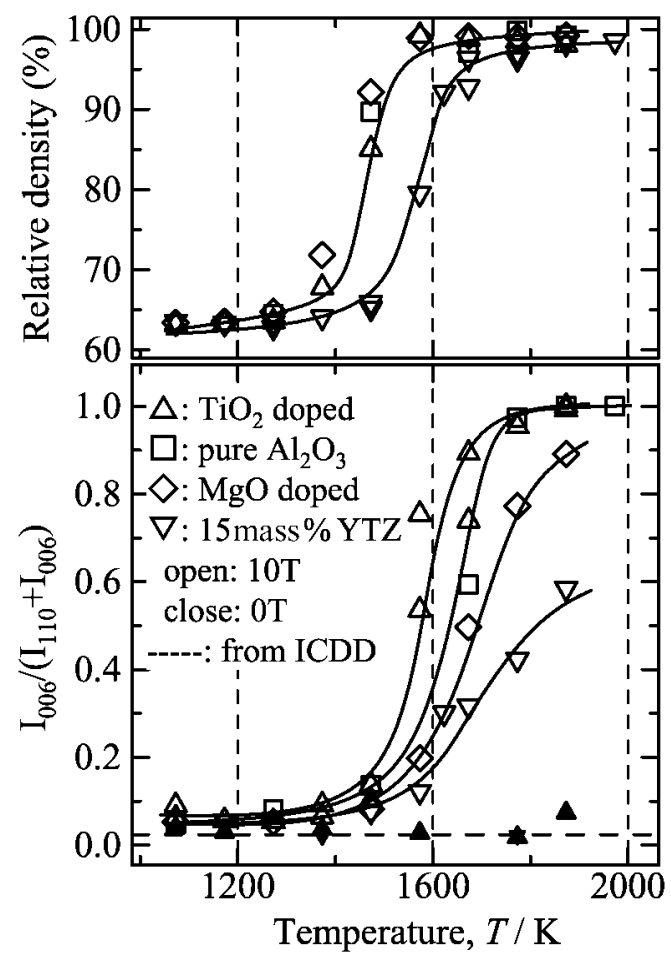

Fig. 3. Effect of temperature on the degree of crystalline texture and density in textured $\mathrm{TiO}_{2}$-doped, $\mathrm{MgO}$-doped and TZP-dispersed $\mathrm{Al}_{2} \mathrm{O}_{3}$.

sintering temperature for the specimens prepared by slip casting in a strong magnetic field of $10 \mathrm{~T}$ (the open plots), and the specimens prepared without applying a magnetic field (the closed plots). Both $\mathrm{TiO}_{2}$ and $\mathrm{MgO}$ enhanced the sinterability of $\mathrm{Al}_{2} \mathrm{O}_{3}$, and $\mathrm{YTZ}$ particles inhibited the sinterability of $\mathrm{Al}_{2} \mathrm{O}_{3}$ composites. For the specimens without an applied magnetic field, the degrees of crystalline texture, $P$, agreed with the value of 0.025 that was calculated from the ICDD. The specimen prepared without a magnetic field was confirmed to have a randomly oriented polycrystalline structure. By comparison, when a strong magnetic field was applied, the value of $P$ was greater than 0.025 in all specimens, but the difference was small at low sintering temperature from $1073 \mathrm{~K}$ to $1473 \mathrm{~K}$. The temperature ranges in which the value of $P$ increased rapidly were observed in the specimens with applying a magnetic field and the temperature ranges depended on the specimens. The temperature range of the $\mathrm{TiO}_{2}$-doped $\mathrm{Al}_{2} \mathrm{O}_{3}$ sifted toward lower temperature than that of pure $\mathrm{Al}_{2} \mathrm{O}_{3}$. Contrary to this, the temperature range of the $\mathrm{MgO}$-doped $\mathrm{Al}_{2} \mathrm{O}_{3}$ sifted toward higher temperature than that of pure $\mathrm{Al}_{2} \mathrm{O}_{3}$. For YTZ-dispersed $\mathrm{Al}_{2} \mathrm{O}_{3}$, the temperature range was found to be wide and the value of $\mathrm{P}$ was the lowest.

Figure 4 shows SEM images of the textured $\mathrm{Al}_{2} \mathrm{O}_{3}$ containing various additives and the textured YTZ-dispersed $\mathrm{Al}_{2} \mathrm{O}_{3}$ composite prepared by slip casting in $10 \mathrm{~T}$ and sintered at $1873 \mathrm{~K}$ for $2 \mathrm{~h}$. It can be seen that the platelet grains are oriented perpendicularly to the magnetic field in pure $\mathrm{Al}_{2} \mathrm{O}_{3}$ shown in Fig. $4(\mathrm{a})$. In $\mathrm{TiO}_{2}$-doped $\mathrm{Al}_{2} \mathrm{O}_{3}$ shown in Fig $4(\mathrm{~b})$, the grain size was larger than that of pure $\mathrm{Al}_{2} \mathrm{O}_{3}$ because $\mathrm{TiO}_{2}$ enhanced the grain growth of $\mathrm{Al}_{2} \mathrm{O}_{3}$ and equiaxed grains were observed. ${ }^{16)-18)}$ In $\mathrm{MgO}$-doped $\mathrm{Al}_{2} \mathrm{O}_{3}$ shown in Fig 4(c), the grain growth of $\mathrm{Al}_{2} \mathrm{O}_{3}$ was suppressed by $\mathrm{MgO}$ and equiaxed grains were also observed. ${ }^{19)}$ Moreover in YTZ-dispersed $\mathrm{Al}_{2} \mathrm{O}_{3}$, shown in Fig $4(\mathrm{~d})$, the $\mathrm{Al}_{2} \mathrm{O}_{3}$ grain size was the
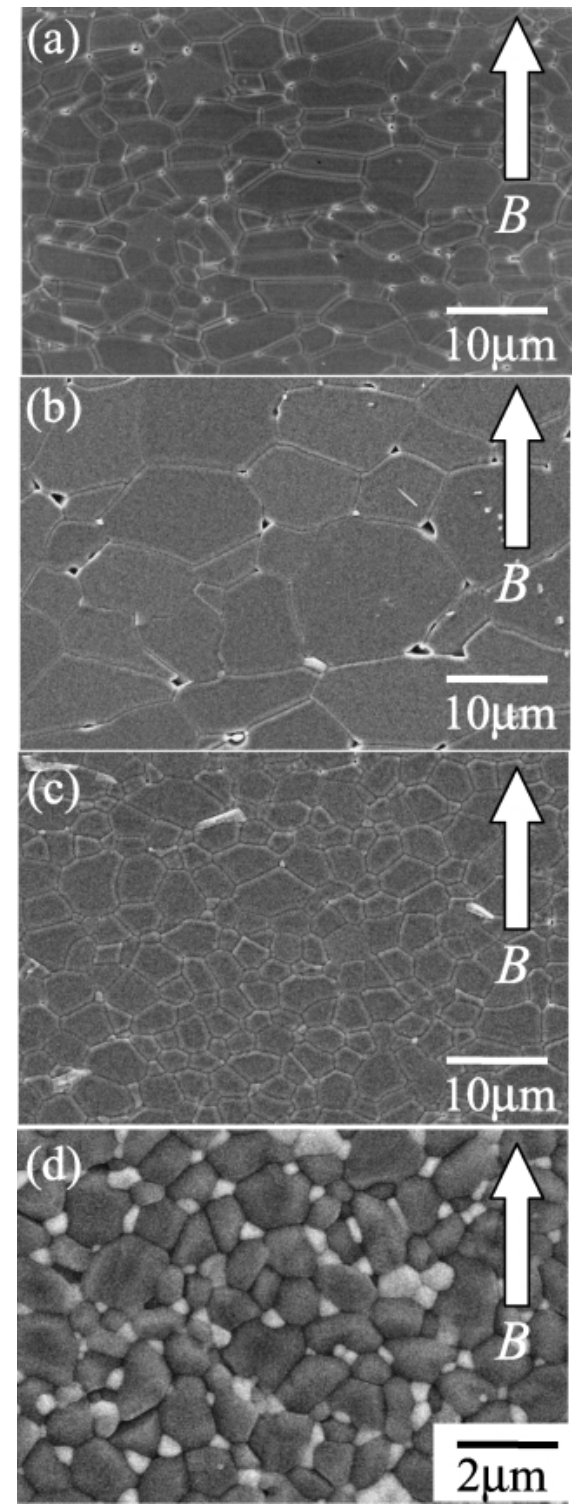

Fig. 4. Microstructures of crystalline oriented $\mathrm{Al}_{2} \mathrm{O}_{3}$ sintered at $1873 \mathrm{~K}$ for $2 \mathrm{~h}$. (a) undoped, (b) $\mathrm{TiO}_{2}$-doped, (c) $\mathrm{MgO}$-doped, (d) 15 mass $\%$ YTZ-dispersed.

smallest because suppression of the $\mathrm{Al}_{2} \mathrm{O}_{3}$ grain growth was controlled by the pinning effect of YTZ particles. ${ }^{20), 21)}$ It should be noted that the scale in Fig. 4(d) is different from the others.

In $\mathrm{TiO}_{2}$-doped $\mathrm{Al}_{2} \mathrm{O}_{3}$, grain growth was enhanced and the temperature range in which the value of $P$ increased rapidly shifted toward lower range than that of pure $\mathrm{Al}_{2} \mathrm{O}_{3}$. On comparison, in both $\mathrm{MgO}$-doped and $\mathrm{YTZ}$-dispersed $\mathrm{Al}_{2} \mathrm{O}_{3}$ the grain growth was suppressed and the temperature range in which $P$ increased sifted toward higher range than that of pure $\mathrm{Al}_{2} \mathrm{O}_{3}$. Therefore, the development of texture in $\mathrm{Al}_{2} \mathrm{O}_{3}$ seems to require grain growth. The dependence of $P$ on the grain size is shown in Fig. 5. In the case of the starting $\mathrm{Al}_{2} \mathrm{O}_{3}$ powder having the same particle size, all experimental data plots were approximately on a curve. The degree of orientation depended on the grain size even if other factors, such as the kind of dopant, the amount of the second phase, sintering temperature, annealing temperature, annealing time, controlled the $\mathrm{Al}_{2} \mathrm{O}_{3}$ grain growth. 


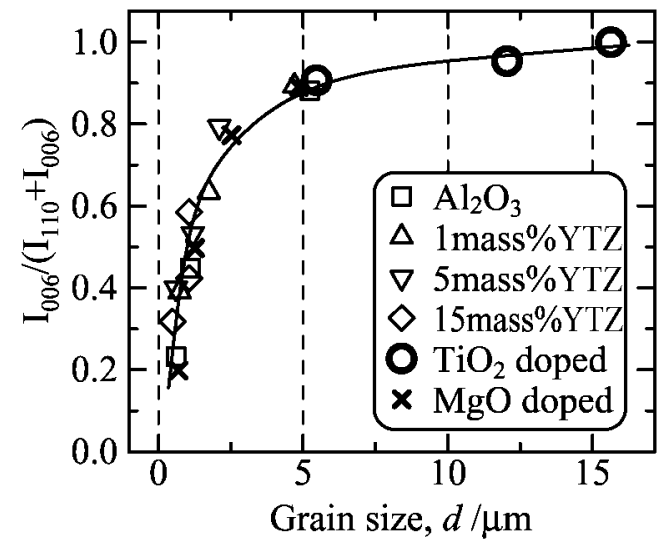

Fig. 5. $\mathrm{Al}_{2} \mathrm{O}_{3}$ grain size dependence for the degree of orientation in the textured specimens.

\section{Summary}

This processing technique for the development of a texture can be applied to $\mathrm{Al}_{2} \mathrm{O}_{3}$ based composites, such as $\mathrm{ZrO}_{2}$-dispersed $\mathrm{Al}_{2} \mathrm{O}_{3}, \mathrm{TiO}_{2}$-doped $\mathrm{Al}_{2} \mathrm{O}_{3}, \mathrm{MgO}$-doped $\mathrm{Al}_{2} \mathrm{O}_{3}$. The degree of crystalline orientation can be controlled by the $\mathrm{Al}_{2} \mathrm{O}_{3}$ grain size. The development of the microstructure can be controlled by many factors, such as the amount of a second phase, various additives, sintering temperature and annealing time.

Acknowledgments This study was partially supported by the Budget for Nuclear Research of the Ministry of Education, Culture, Sports, Science and Technology and also partially by the Ministry of Education, Culture, Sports, Science and Technology, Grant-in-Aid for Scientific Research (\#16560596 and \#15560593).

\section{References}

1) Ma, Y. and Bowman, K. J., J. Am. Ceram. Soc., Vol. 74, pp. 2941-2944 (1991).

2) Brandon, D., Chen, D. and Chan, H., Mater. Sci. Eng., Vol. A195, pp. 189-196 (1995).

3) Seabaugh, M. M., Kerscht, I. H. and Messing, G. L., J. Am. Ceram. Soc., Vol. 80, pp. 1181-1188 (1997).

4) Suvaci, E. and Messing, G. L., J. Am. Ceram. Soc., Vol. 83, pp. 2041-2048 (2000).

5) Teshima, H., Hirao, K., Toriyama, M. and Kanzaki, S., J. Ceram. Soc. Japan, Vol. 107, pp. 1216-1220 (1999) [in Japanese].

6) Beaugnon, E. and Tournier, R., Nature, Vol. 349, pp. 470-470 (1991).

7) Hirota, N., Homma, T., Sugawara, H., Kitazawa, K., Iwasaki,
M., Ueno, S., Yokoi, H., Kakudate, Y., Fujiwara, S. and Kawamura, M., Jpn. Appl. Phys., Vol. 34, pp. L991-L993 (1995).

8) Morikawa, H., Sassa, K. and Asai, S., Mater. Trans., JIM, Vol. 39, pp. 814-818 (1998).

9) de Rango, P., Lees, M., Lejay, P., Sulpice, A., Tournier, R., Ingold, M., Germi, P. and Pernet, M., Nature, Vol. 349, pp. 770-772 (1991).

10) Stassen, S., Cloots, R., Vanderbemden, Ph., Godelaine, P. A., Bougrine, H., Rulmont, A. and Ausloos, M., J. Mater. Res., Vol. 11, pp. 1082-1085 (1996).

11) Suzuki, T. S., Sakka, Y. and Kitazawa, K., Adv. Eng. Mater., Vol. 3, pp. 490-492 (2001).

12) Suzuki, T. S. and Sakka, Y., Jpn. J. Appl. Phys., Vol. 41, pp. L1272-L1274 (2002).

13) Suzuki, T. S. and Sakka, Y., Chem. Lett., pp. 1204-1205 (2002).

14) Suzuki, T. S. and Sakka, Y., Scripta Materialia, Vol. 52, pp. 583-586 (2005).

15) Lange, F. F., J. Am. Ceram. Soc., Vol. 72, pp. 3-15 (1989).

16) Horn, D. S. and Messing, G. L., Mater. Sci. Eng., Vol. A195, pp. 169-178 (1995)

17) Kim, Y.-M., Hong, S.-H. and Kim, D.-Y., J. Am. Ceram. Soc., Vol. 83, pp. 2809-2812 (2000).

18) Kebbede, A., Parai, J. and Carim, A. H., J. Am. Ceram. Soc., Vol. 83, pp. 2845-2851 (2000).

19) Ikegami, K. and Eguchi, K., J. Mater. Res., Vol. 14, pp. 509-517 (1999).

20) Okada, K. and Sakuma, T., J. Ceram. Soc. Japan, Vol. 100, pp. 382-386 (1992).

21) Hori, S., Kurita, R., Yoshimura, M. and Sōmiya, S., J. Mater. Sci. Lett., Vol. 4, pp. 1067-1070 (1985).

22) Uchikoshi, T., Sakka, Y., Ozawa, K. and Hiraga, K., J. Eur. Ceram. Soc., Vol. 18, 669-674 (1998).

23) Hirata, Y. and Aksay, I. A., pp. 3-15 in Advances in Materials, Processing and Manufacturing, Proceedings of the Advanced Materials Technology Ceramic Workshop, No. 4. International Committee for Advanced Materials Technology, Nagoya, Japan, 1988.

24) Kimura, T., Takenaka, A. and Yamaguchi, T., Advanced Materials '93, I/A; Ceramics, Powders, Corrosion and Advanced Processing, edited by N. Mizutani et al. Trans. Mat. Res. Soc. Jpn., Volume 14A (1994) pp. 793-796.

25) Suzuki, T. S., Sakka, Y. and Hiraga, K., J. Jpn. Soc. Powder and Powder Metall., Vol. 44, pp. 356-361 (1997) [in Japanese].

26) Suzuki, T. S., Sakka, Y., Nakano, K. and Hiraga, K., J. Am. Ceram. Soc., Vol. 84, pp. 2132-2134 (2001).

27) Suzuki, T. S., Sakka, Y., Nakano, K. and Hiraga, K., Mater. Trans., JIM, Vol. 39, pp. 689-692 (1998).

28) Cesarando, J., III, Aksay, I. A. and Bleier, A., J. Am. Ceram. Soc., Vol. 71, pp. 250-255 (1988).

29) Aksay, I. A., Lange, F. F. and Davis, B. I., J. Am. Ceram. Soc., Vol. 66, pp. C190-C192 (1983). 